\title{
The Ancestors of the Ixil Maya of Guatemala: oral tradition and the pre-Columbian sites in Ilom
}

\author{
Monika BANACH
}

\begin{abstract}
The article is a brief reflection on the oral traditions of the Ixil Maya of the highlands of Guatemala, which concern in particular the supernatural beings that are believed to inhabit the pre-Columbian remains located in the sacred place of B'ayal I' ('Xacbal' archaeological site) close to the contemporary indigenous community of Ilom in the municipality of Chajul. It aims to show how the inhabitants of Ilom imagine, verbalize and perform their bonds with the remains of the people they call the Grandfathers, what is left of the time they lived in the vicinity of where their descendants live right now, and what it means for them to co-habit their ancestral lands. The article is based on selected historical sources and materials from the fieldwork conducted in the Ixil Region between 2013-17.
\end{abstract}

Keywords: Ixil Maya, Ilom, oral traditions, sacred landscape, creation myth

Monika BANACH PhD candidate at the Institute of Ethnology and Cultural Anthropology, Jagiellonian University, holds an MA in Latin American Studies. Her research interests include Maya religious practices, sacred landscape, human rights and environmental justice. E-MAIL: mj.banach@gmail.com 
After hundreds of years of forced displacement and deprivation of property, the Indigenous communities' legacy and right to their ancestral lands is often still disregarded. In the Ixil Region those continuous processes are viewed as the "Four Invasions", a local concept that refers to the Spanish Conquest, the arrival of coffee plantations and land expropriation and displacement in the late 19th and early zoth century, the Guatemalan Civil War 1960-96, and the imposition of Western models of development in the current era (the construction and implementation of foreign megaprojects, such as dams and mining on their ancestral lands) ${ }^{1}$. At the same time, some ongoing related changes like the growing importance of Evangelical churches and the cultural revitalization movement, are influencing local worldview, religious practices, and perception of the sacred landscape witihn it. In the face of these changes, the narratives associated with the mythical ancestors that are believed to dwell in the sacred locations are reinterpreting their traditional role, as they continue to stand firm on behalf of their communities, legitimating their rights and their resistance.

This article represents one element of a research project conducted between $2013^{-17}$ on the dynamics of the relationships between people and the sacred landscape in the context of the historical and modern factors that affect the Ixil Maya communities from the El Quiché Department situated in the western highlands of Guatemala. In spite of significant differences in their worldview (as well as the three Ixil language varieties, distinct dress patterns, among others) the people of the three municipalities of Nebaj, Chajul and Cotzal usually identify as ixiles and generally speak of their common land as Región Ixil (the Ixil Region). There is also a number of K'iche' and Q'anjob'al communities that live among the Ixil. The majority of those who live in the Ixil Region work in agriculture, mainly cultivating maize, beans, cucurbits as well as coffee and cardamom due to the presence of several plantations.

This article focuses on the oral traditions associated with the supernatural beings that are believed to inhabit pre-Columbian building remains located close to the contemporary Indigenous community of Ilom in the municipality of Chajul. It aims to show how the inhabitants of Ilom imagine, verbalize and perform their bonds with the people they call the Ancestors,

1 For a complete study of the concept of the Four Invasions in the Ixil Region see G. Batz, The Fourth Invasion: Development, Ixil-Maya Resistance, and the Struggle against Megaprojects in Guatemala. 
the Ancients or Grandfathers, their physical remains, what is left of the time they lived in the vicinity of where their descendants live right now, and what it means for them to co-habit their ancestral lands.

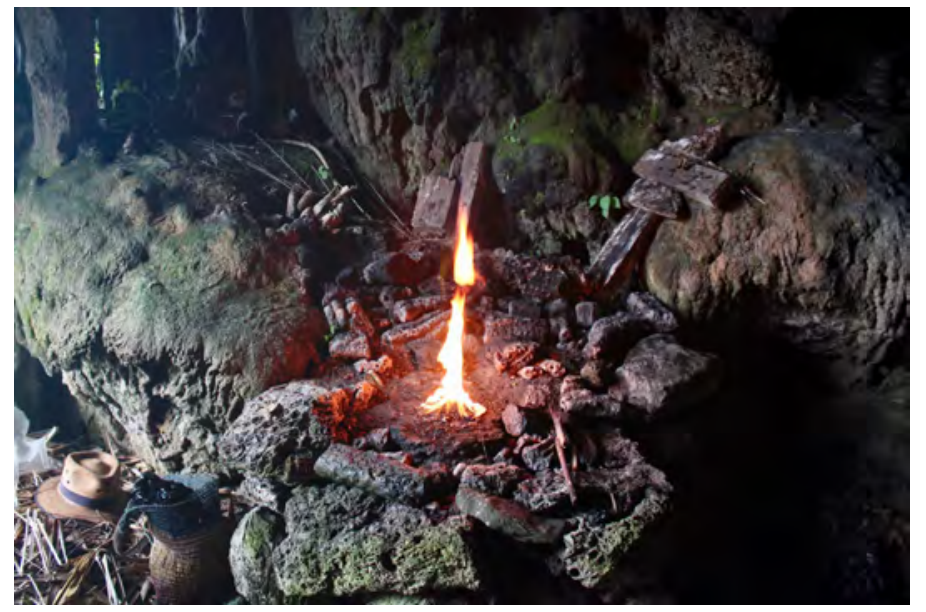

\section{Historical and Ethnographic Background}

Despite the significant regional differences, the narratives concerning the multiple creations and destructions of the world and the appearance of consecutive humanities are a widespread concept in the Maya world and in Mesoamerica. J. Eric S. Thompson ${ }^{2}$ describes some examples from archeological and colonial sources. When it comes to the highland Maya, Thompson draws attention to the creation myth described in historical sources such as the K'iche' book of Popol Vuh (which we shall further discuss below) and the Annals of the Kaqchiquels. There are also narratives that contain the concept of multiple creations of the world in the ethnographies known to the author, told by different groups of the Maya people: the Tz'utujiil, Mam, Q'anjob'al and Jakalteka, by the Yukatek, by the Mopan and Q'eqchi', by the Lacandon and Palencano Ch'ol, and by the Tzotzil and Tzeltal. Some of them resemble the Ixil narratives that we are going to read - where the considered as imperfect past humanity, frequently associated with the remains of the pre-Columbian buildings, suffers death in a rainfall of fire.

Garry H. Gossen ${ }^{3}$ presents an example of the "true ancient narrative" that the people of Chamula relate referring to the first three of four consecutive

2 J. E. S. Thompson, Maya History and Religion, p. 330-348.

3 G. Gossen, Chamulas in the World of the Sun, p. 140-158. 
creations of humankind, whose latter version represents the people of today. In the same time Gossen underlines that the intervals of time between those periods are relative - they may refer to the previous generation or to the oldest of all generations, as well as to relatively recent times. The fragment below shows an interesting event described in the narrative titled The Destruction of the First People, where demons emerge from objects of everyday use and devour humans:

They broke their pots. In that way, they broke many of their pots right away. And so, when the earth had darkened, those pots spoke. At once the pots (spoke). Well, when it darkened, the demons came forth (from the broken pots). The lion, the snake, the jaguar came forth. Thus the poor people perished in the jaws of the demons. (...) These people perished in their houses. When the dawn came upon the earth, there was no longer a single person left ${ }^{4}$.

There are also elements of the concept of multiple creations in the oral tradition of Jacaltenango, especially in the narrative titled El Genesis facalteco collected by Oliver La Farge and Douglas Byers ${ }^{5}$. Here, the punished humanity is believed to be the Spaniards (los españoles) who were killed by the sun that rose when Jesus was born. The Spaniards tried to escape and hide in caves or under the water, but as they caught sight of the rays of the sun, they died anyway. The people that succeeded them were the children of Adam and Eve and are the ones that now live in the place close to the Ajul mountain called Sat B'ak'uh where the remains of the ancient buildings are, and where the first ceremony of the Yearbearer was held. According to the authors, this narrative is associated with the use of the "images" (probably pre-Hispanic artifacts) hidden in the forests and caves, a custom widespread among the people of the highlands.

As previously mentioned, one of the historical sources that illustrates the concept of the creation of the world and the appearance of the consecutive humanities is the K'iche' Maya book of Popol Vuh that are considered to be an intertwining of indigenous and European narratives with new meanings emerging in a dialogic relationship ${ }^{6}$. According to Robert M. Carmack, the

4 Ibidem, p. 148-149.

5 O. La Farge and D. Byers, El Pueblo del Cargador del Año, p. 112-114.

${ }^{6}$ See T. Knowlton, Maya Creation Myths, p. 132. 
creation account is one part of the Popol Vuh most influenced by Christian thought, but the multiple creations in turn would be particularly indigenous, especially the motive of the resin rain that destroys, as we will see, one of the consecutive humanities made of wood ${ }^{7}$. The problem with such a "selection" of certain elements of the text and their assignation to either indigenous or European thought is that, as representatives of the latter, we are practically unable to draw a straight line between them. Therefore, Dennis Tedlock suggests here a hermeneutical approach "in which questions of culture history are held in abeyance long enough to get the drift, to hear the tenor, to follow the path, to see the world of the text before us. Comparison is still open to us here, but it is a comparison of tenor and paths and worlds rather than of artifacts" ${ }^{\text {. }}$. Below I will recall some key K'iche' ideas that refer to the creation of the consecutive humanities in the Popol Vuh and that may help us "to follow the path" of the contemporary narratives from the Ixil communities.

The divine idea of creating humans that would be able to speak takes the gods four attempts. Firstly, they bring animals to life but seeing that they can't worship them and their speech is unrecognizable, the gods decide to replace them. In the second attempt, people are made from mud, but even if at the beginning they show some slight signs of communication skills, they quickly dissolve in the water and in the end the gods decide to destroy them. The chapter that follows describes the creation of the effigies of carved wood that would possibly be able to speak ${ }^{9}$. They were the first population of any serious number that inhabited the world, who had the appearance of people and some ability to communicate. The wooden men were made of $t z^{\prime}$ ite wood $^{10}$ and the women of reeds, and they begun to reproduce so that they finally populated the whole world. But even then, it soon became clear that they didn't have hearts or minds, so they lacked a "purpose" and could not remember who had created them. Because of these serious defects, the gods were not satisfied with the outcome of this attempt either, so they decide to kill the wooden people. The following fragments describe the moment of their extermination:

7 R. M. Carmack, The Quiché Mayas of Utatlán. The Evolution of a Highland Guatemala Kingdom, p. 318.

${ }^{8}$ D. Tedlock, Creation in the Popol Vuh: A Hermeneutical Approach, p. 79.

9 A. J. Christenson, Popol Vuh. Sacred Book of the Quiché Maya People, p. 68-73.

${ }^{10}$ The characteristic red $t z^{\prime}$ ite wood grains in Popol Vuh as well as in today's highland Maya communities are used for divination. In Chajul Ixil it's called mitx or palo de pito (Erythrina berteroana). 
Then came the end of the effigies carved of wood, for they were ruined, crushed, and killed. A flood was planned by Heart of Sky that came down upon the heads of the effigies carved of wood. (...) Thus they were killed in the flood. There came a great resin down from the sky. (...) Their bones were ground up. They were broken into pieces. Their faces were ground up because they proved to be incapable of understanding before the face of their mother and the face of their father, Heart of Sky, Huracan by name. Thus they caused the face of the earth to be darkened, and there fell a black rain, a rain that fell both day and night. The small and the great animals came in upon them. Their faces were crushed by the trees and the stones. They were spoken to by all their maize grinders and their cooking griddles, their plates and their pots, their dogs and their grinding stones. However many things they had, all of them crushed their faces ${ }^{11}$.

We understand that the annihilation of the wooden people came in four phases. Firstly, the flood was planned by the Heart of Sky, although it may not have been a deluge that would correspond to our understanding - the "great resin" that comes "down from the sky" (according to Christenson, the text may refer to resin, sap, or turpentine, all of them being secretions of pine trees) may instead be something associated with fire. Another punishment is the revenge of the animals for the pain that the wooden people had caused them - because they had chased them out, starved and beat them, they would become their food from now on. Then there is a short mention that stones and trees crushed the faces of the wooden people. The fourth punishment comes from the objects of everyday use - maize grinders, cooking griddles, plates and pots become to destroy the faces of the people, saying: "(...) you were forever throwing us upon the fire and burning us. Although we felt no pain, you now shall try it. We shall burn you"12. Then, the hearthstones also came out of fire and flattened their bodies and their heads. The tortured wooden people intended to flee in a hurry:

They fled. They hurried away. They wanted to climb up on top of the houses, but the houses would fall apart beneath them and they were thrown off. They wanted to climb up to the tops of

\footnotetext{
${ }^{11}$ Ibidem, p. 73-75.

${ }^{12}$ Ibidem, p. 77.
} 
the trees, but the trees would not support them. They wanted to hide in caves, but the mouths of the caves closed up before their faces $^{13}$.

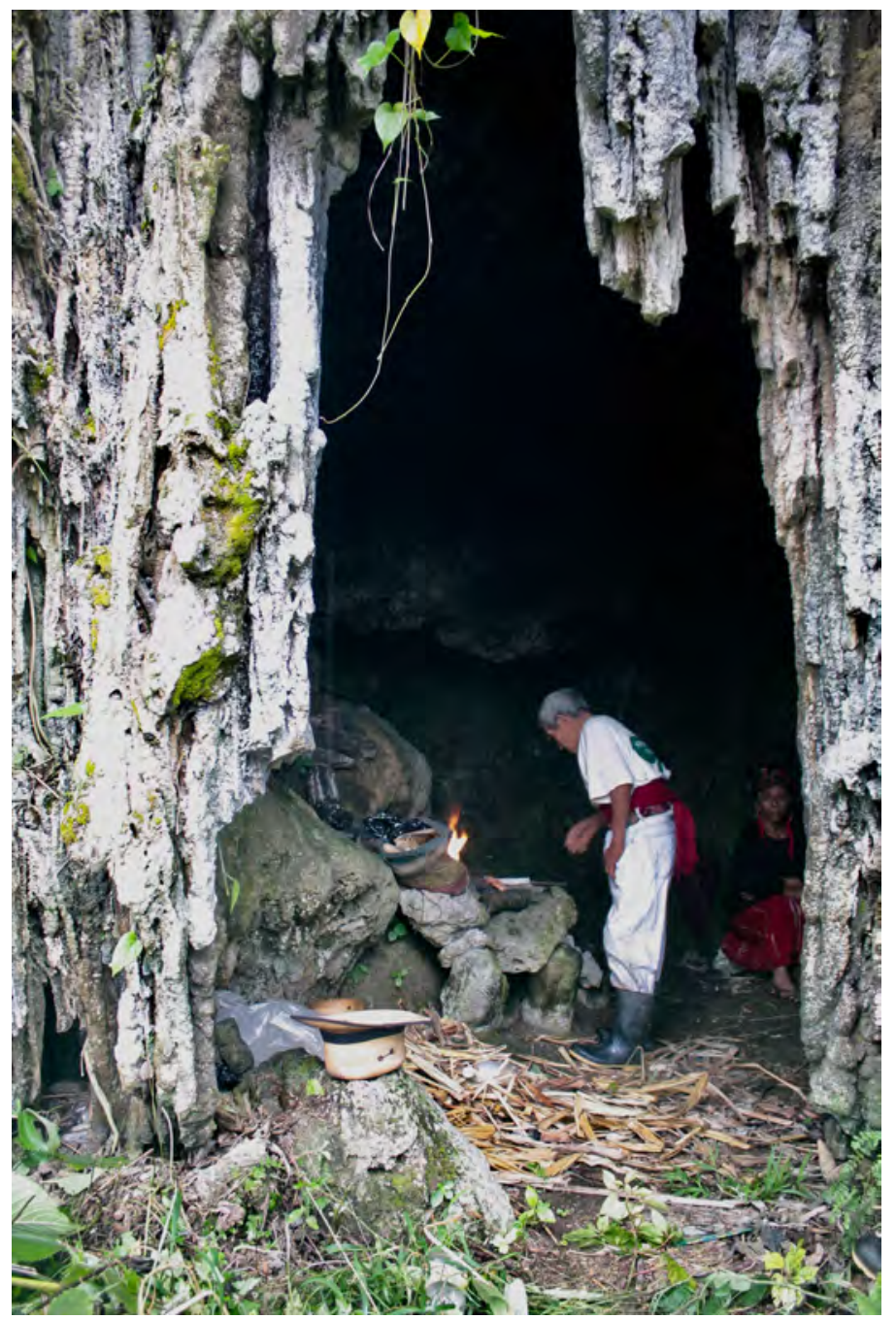

After eliminating the wooden effigies, the successful creation of humankind was not accomplished until the gods had received notice from the animals about the mountain-source of maize, which would finally become the new material for creating human bodies.

${ }^{13}$ Ibidem, p. 77. 


\section{K'uykumam - the Ancestors of Ilom}

\subsection{Sacred places and rituals}

In the Ixil Region, the Ancestors or the K'uykumam (Grandfathers) are believed to live in the sacred mountains or sometimes, the mountains themselves personalize them. The Ancestors are known to dwell in caves, rocks, water springs but also in the old places where they used to live - in the remains of pre-Columbian buildings. In many of these sacred locations there are places of prayer called in Chajul Ixil katchb'al or in Spanish rezaderos, which are often marked with wooden crosses. The Mama', experts of the count of the Ixil Maya ritual calendar (the Daykeepers), visit those places and pray for important community matters. They perform sajb'ichil or el costumbre (ceremonies) where they burn candles, copal and incense as an offering to the Ancestors; they ask for forgiveness, prosperity, protection for the community and its resources. In their prayers, the ritual language of Christian and Mayan heritage intertwines while recounting the cosmogonic events. The fragment below is one of the prayers I have heard in the sacred place on the top of the Vi' Kooma mountain in a ritual performed by one of the Mama' from Ilom, Pap Laas:

And then he said: take a seat, you, of the religions, and take these ma'tz [maize dusts], Yoxhilivinq'elal [The God of the Twentieth], ${ }^{14}$ Vi' Vitz, K'oj Vitz, Ab'inal Vitz. ${ }^{15}$ We have already achieved [to get the maize]. What are we going to do? What we are going to do is that we are going to take the ma'tziltoj [maize dust from our feet], and the ma'tzilqab' [maize dust from our hands]. The maize dust will begin to sprout. When you will see it sprouting, so you will put it in to a groove, saq tub'e'n [the white bean], kaq tub'e'n [the red bean], a day and night, and then 60 days and 60 hours. When it gets ripe, it will get white, red [stains?], that's how will it arrive to Atimb'al I'lamb'al [the Place of Rest]. (Pap Laas, Ilom, Chajul)

\footnotetext{
${ }^{14}$ Probably a reference to the sacred twenty days of the Ixil ritual calendar.

${ }^{15}$ Names of other sacred mountains.
} 


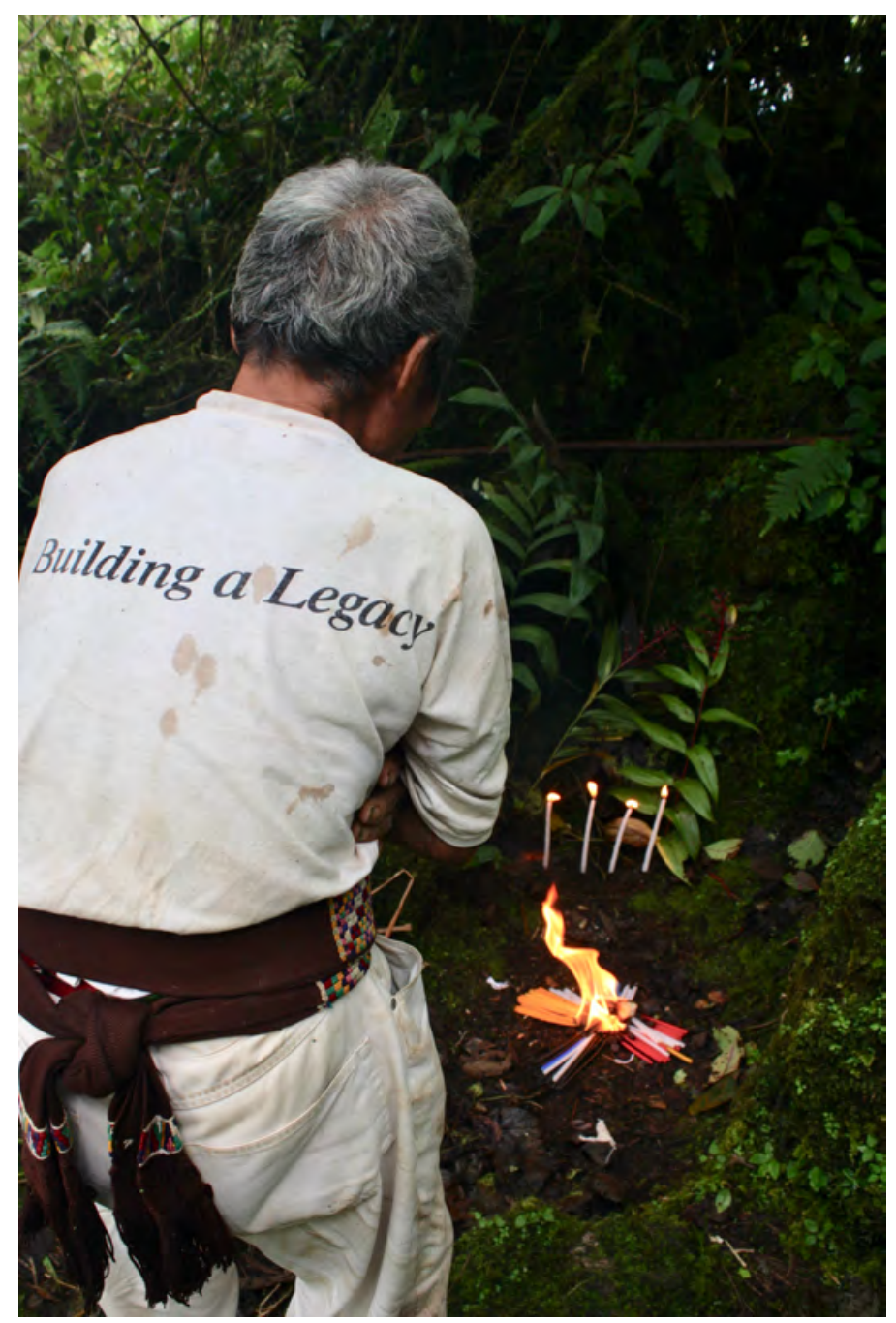

According to the oral tradition, the Ancestors that inhabited the place called B'ayal I' or Xe' Kuxhab'16 (known among the archaeologists as "Xacbal") were the people of the past generation that settled in todays Ilom, originally called Atimb'al I'lamb'al. They were known as the Lacandon ${ }^{17}$

${ }^{16}$ In Ixil the place is called B'ayal I' (the Wild Cane) or Xe' Kuxhab' (the Place of Achiote). The "La Perla" coffee plantation owner Luis Arenas then renamed it as "La Panchita". Around 2004 it was sold to a company called Hidro Xacbal S.A., subsidiary of honduran Grupo Terra S.A. called by the inhabitants simply la empresa (the company). Later, the archaeological project financed by the company (after the machinery destroyed part of the site) was registered as "Xacbal".

${ }^{17}$ The people referred here as "Lacandons" were probably the ones referred as such in the 
and were the same group of people that now identify themselves as Chajul Ixil. They came from the north, from Ixcan or the rainforests of Peten and settled in the valley of the Xakb'al river. Not only did they build their houses there but they also constructed meeting places for the authorities, established places of prayer and started maize cultivation. Since then, all of the land around Ilom belonged to the Ancestors.

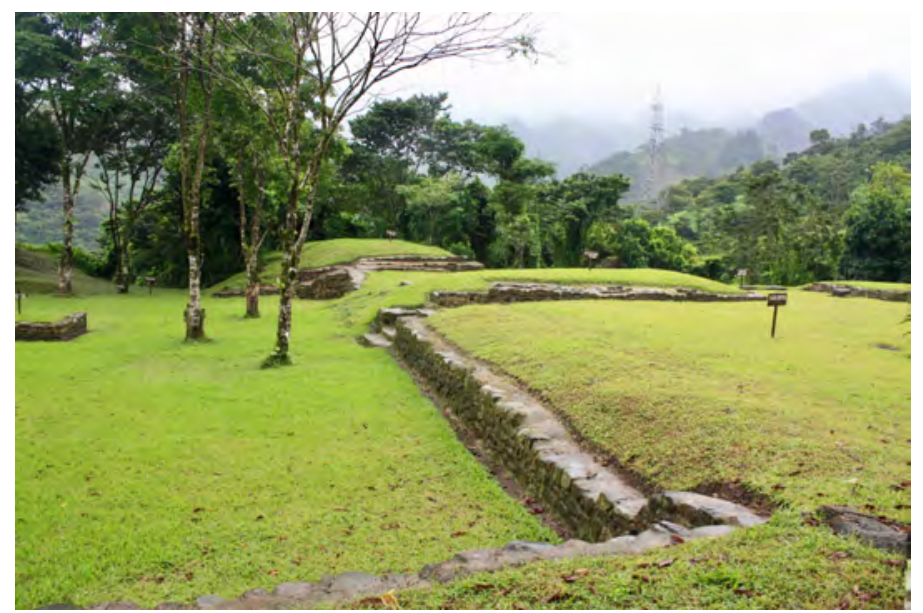

Archaeological research has shown that the "Xacbal" archaeological site was a place with potentially defensive characteristics, with structures associated with worship (three temples and two altars) and administration, as well as housing. It was inhabited uninterruptedly between 500 BC (Middle Preclassic) and $1530 \mathrm{AD}$ (Late Postclassic period). Archaeologists have related the first inhabitants of this complex with the people from Chiapas and the Usumacinta river basin. There are many more archaeological sites located around Ilom, covered by contemporary housing or milpas. ${ }^{18}$ Some of them, like B'ayal I', are also considered as sacred places ${ }^{19}$.

Don Bernal, one of the elders of Ilom, a former Daykeeper (now attending one of the Evangelical churches), describes the remains of the pre-Columbian buildings that he observed while working the milpa at B'ayal I':

colonial documents and were one of the Ch'ol speaking groups. The modern Lacandons are the people that came from the east and west of the Usumacinta River, after the conquest of the historical Ch'ol Lacandons (i.e. de Vos 1988: 121; Thompson 1938).

${ }^{18}$ The main archaeological sites located around Ilom are: Verdun, Ilom, Sacsiguan, Maravilla, Mapalpa, Sotzil, Potrero Grande, Potrerito, Finca La Perla, Chel, Estrella Polar, Covadonga. There are also pre-Columbian buildings that are not registered but recognized by the local people as sacred places, like for example Kutchmaltostiiuxh.

${ }^{19}$ B. Hermes and J. L. Velásquez, Análisis de La Cerámica Arqueológica de Xacbal, Chajul, Quiché: Períodos Preclásico y Clásico Temprano. 
Back then, at La Panchita, where the company is now, there were these great boxes, these great canals! This [house] is nothing! We were always ploughing the milpa over there, the plantation was ploughing it back then, so that's why we went there to work. We saw "volcanoes" this big! Yes, the "volcanoes" like the ones for the bread-baking oven, like for the bakery, that's how it looked like. It was something like this, a round thing, but not small, no, these were huge, like this high. So I heard that people were saying that this was the house of our Ancestors. (...) Not only here but in Ixcan, they say, in San Luis, they say, and here. In many places there are their crops. But who knows why, surely the Ancient people were everywhere, who knows why. (Don Bernal, Ilom, Chajul)

According to the oral tradition of Ilom the Ancestors possessed supernatural abilities and physical features. They had advanced skills and technologies that enabled them to create monumental buildings and to develop quality tools or to make objects of gold. They also made good clothes, although some say that they were naked and only covered "the most important parts" with malanga (Xanthosoma) leafs, and braided their long hair with twigs. The ancient people had communication with nature; they could speak with trees and stones, and they had "a lot of secrets, a lot of magic, because they used [it] to transform into birds, into chickens, into roosters, into any type of animal" (Nan Lo'xh, Ilom, Chajul). They were smart enough to predict the future and they used divination to foresee the agricultural cycle and make sure their crops were abundant and to avoid any threat. The Ancestors were the ones who first effectuated the costumbre (ceremonies), and taught their inheritors how to pray to their god, whom Don Bernal calls the God of the Ancients:

The Ancients lived there [at the sacred place of Txinaq'i]. Because, when they made costumbre, the Ancients, the Ancestors, when they made costumbre, they were the ones who showed how they were doing it, they showed it to other people so that they might continue, [and] because of this they were looking for them. (...) So let's say that I am [one of these] crosses, and you are the one that is asking me for anything that your heart wants: "Look Lord, my god..." - because he is the God of the 
Ancients; then you say - "give me some money" or "give me my life" or "give me my animals" or "give my family" or "give me...", and anything we want. This is what they would say, the ones that were praying, they went to make their costumbre, they would ask for something good, or maybe some [of them] asked for some bad things for the people... I don't know. (Don Bernal, Ilom, Chajul)

\subsection{Tx'ol Winaq}

The people of Ilom distinguish one specific person among the Lacandons - a man called Tx'ol Winaq (winaq - man) who is known to reappear in different crucial moments of the history of Ilom and the Ixil Region. The complex story of Tx'ol Winaq seems to illustrate the concept of the Four Invasions that Giovanni Batz described from the example of the Cotzal Ixil communities $^{20}$. Although a complete analysis of the narrative in this context is beyond the scope of this article, I will refer here to some elements that I consider interesting from the point of view of the topic under discussion. Don Francisco, one of the inhabitants of Ilom describes the arrival of Tx'ol Winaq as follows:

This is the first one of our Grandfathers that came here. They say that he came out at Tzi' Jul A'. ${ }^{21}$ This is where they found him, close to the village, the first time that the people came here to work. Because our Grandfathers were the first that came here, before Christ, 2,60o years ago the people came here. In turn Jesus came 2,016 years ago, our Grandfathers came first, long time ago they came here to Ilom! Our name was the Lacandons, this was our name because here is where the Tx'ol was. (Don Francisco, Ilom, Chajul)

It is significant in what circumstances the people positioned in the oral tradition as belonging to the current generation of the people of Ilom (or the one that follows the Ancients) were able to meet Tx'ol Winaq. While they

${ }^{20}$ G. Batz, The Fourth Invasion: Development, Ixil-Maya Resistance, and the Struggle against Megaprojects in Guatemala.

${ }^{21}$ Refers potentially to two sacred places located in Ilom: a water spring Jul A' and a stone formation Tzi' Jul A'. 
were working in the field after one of the historic migrations between Chajul and Ilom (probably the one that is estimated around the 1775$)^{22}$, an unusual event happened - according to Doña Teresa from Ilom, this is how this first meeting with Tx'ol Winaq looked:

The first people came here, it was Tx'ol Winaq and later other men came from Chajul. They came to sow chili here in Ilom. Tx'ol Winaq was in Tzi' Jul A', he climbed a fruit tree, saj kaq' [guava], and when the people wanted to cook something, it was already cooked. And when the people came back [from work] it was ready but... there was no one there. The people were going to eat and he had already prepared atole and everything was ready: their tortillas, coffee, atole. In a moment they heard something like this: "tx'ololololol, tx'ololololol!", and the people saw that it was Tx'ol on the guava tree. It was a person; his father came from Ixcan, that's where he came from. His father was traveling to bring the salt over there, at the bottom of the mountain Xe' K’aj Qub’. (Doña Teresa, Ilom, Chajul)

There seem to be more unusual elements in this fragment of narrative. First of all, Tx'ol Winaq, who is said to be a representative of the past humanity, is the one who prepares the meal for the modern people that re-settled Ilom. Behind their backs he makes their tortillas, coffee and atole (corn gruel) which are, significantly, all processed, cooked, and "culturally transformed" as Lévi-Strauss ${ }^{23}$ would say - elements of the meal. Moreover, we learn, that the father of Tx'ol Winaq had been traveling northwards (through today's community of Estrella Polar) in order to bring salt, which is also symbolically identified as an element used for a technologically more advanced method of processing food. In another narrative told by Nan Lo'xh, we learn some details about Tx'ol Winaq's role in the salt-associated movement. As a child, he was sent by his father to bring the salt from Chajul. On his way back, Tx'ol Winaq, sweating under the weight of the salt bag, meets an old man who asks where was he coming from. When he learnt the purpose of the boy's journey, he warned him against the possible threat of death that may

${ }^{22}$ J. S. Lincoln, Ethnological Study on the Ixil Indians, p. 53; see also Elaine Daly Elliott, Gaspar Ilom: Maya Resistance to the Western Ideology of Nature, p. 12.

${ }^{23}$ C. Lévi-Strauss, The Culinary Triangle. 
be associated with his entrusted task, and recommended an incantation that would help him to flee, having delivered the order.

Therefore, in the context of the narratives that show the achievements that the Ancestors were known of, this may encourage us to interpret the unusual circumstances that accompanied this first encounter with Tx'ol Winaq as another symbol of the Ancestors belonging to the "world of culture" or possibly as being kind of a boundary between the world of culture and nature. On the other hand, their lack of ability to speak in an comprehensible language and the upcoming punishment for their sins that we shall examine shortly, dehumanized them and destabilized this order in a way that forces us to look for different possible interpretations that do not rely on such dichotomies.

\subsection{The annihilation of the Grandfathers}

As the Ancestors developed their divination skills, they begun to build tremendous stairs or a tower made of people that enabled them to reach higher and hear the god's plans better because "they wanted to know and to touch the sun. This was something they wanted the most" (Don Bartolome, Ilom, Chajul). Thanks to this knowledge they could predict what would happen in the future so as to use this information for their own purposes. The god saw them and was angry that they were listening to his "secrets", so he decided to destroy the Grandfathers. As they already knew about the upcoming punishment, around the time of the imminent doomsday they built tombs under their houses in order to hide and wait out their destiny. But this time they could not make it - they burnt to death under the fire rain of $q$ 'ol (pine resin or copal) and until this day they are buried in their stone houses, which became their tombs. Because of this they are sometimes also called Ch'an Q'ol, the people burned by resin. Don Bartolome, a member of the Council of the Principals of Ilom, explains in the following manner what happened to the previous generation of people:

Because of their disobedience, turpentine fell so that they burn. The god did this because they knew what was going to happen tomorrow. They hid, they made their holes to get into so that they wouldn't die, but the fire was strong and they were burned, all of them. It's because they knew what will happen tomorrow, that's why the god got angry with them: because in order to hear 
what the god was planning they made a tower, one of them went first and then another ... they were making a tower of people to hear what the god was planning. (Don Bartolome, Ilom, Chajul)

Nan Lo'xh, a member of the Ilom's Midwifes Council, describes as following the mistake that the people of the ancient I'lamb'al had committed and what happened to them:

They would put up something like a kind of stairway, they would climb and from there they could hear god's plan. So they knew what was going to happen tomorrow, they were already aware. So for sure the god said that there would be no more listening to the god's secrets! So then they said: "there are fire drops coming from the sky, we better make a hole so that the fire sent by the god does not burn us, let's make a hole and we will get in with all of our belongings, so even if he sends the drops of fire we will not burn." So they said. And they started to make their holes and then they entered them. Because they used to make a type of stairway so that they could listen to the god's plans: what will be tomorrow, what would be in the past; they were always aware of the god's plans. As they had their secrets, they had their prayers for how to make it happen, so they would always do it. So in the end the god felt bad and obviously he wanted to kill the people... So then the people, like always, they found out, like today, they have satellites or other kinds of things, they already know. So this is how they made it, they always knew what was going to happen, so he [the god] sent his punishment on them, he planned the punishment and he was going to send the drops of fire. So this is what he had to do but the people some of them survived, others died, but under their pots, under the ground. (Nan Lo'xh, Ilom, Chajul)

A Daykeeper interviewed by Benjamin and Lore Colby in the 1970s told a similar narrative concerning the Ixil Ancestors in the Municipality of Nebaj. According to Pap Xhas Kow, the people of the first creation are associated with the pre-Columbian buildings, as they are thought to be the ones who constructed "the pyramids". Because they considered themselves as equal to the supreme god referred to in the narrative Kub'aal (the Father), he decided 
to destroy them by sending diseases, fire and water. According to one of the variants of the story, they had been able to avoid the diseases by escaping up to the mountain peaks, constructing their houses there, and frightening the sickness with slingshots. They survived the flow of lava by hiding in caves, rivers and water pits. In the end, the first people survived the deluge, building their houses very high and reaching the sky. In another version, it was the fire and lava that destroyed the majority of the ancient people and only those hidden in the water, in the mountains or caves survived. The god was so impressed with their achievements that he pardoned them and called them the aanheles (angels) that are now believed to live in the mountains. The god then put them in charge as a guardians of the new generation of peoples that were to be created soon, to take care of their issues and necessities - he ordered them to observe the new people and make sure that they feed them (make offerings to them) $)^{24}$.

\subsection{Kamawiil}

Certain Ixil narratives associated with the Ancestors explain the origin and significance of the objects that were left after their punishment - the kamawiil. Usually the term kamawiil refers to ceramics, tools, bones (or bones converted to stones) that can be found in the remains of pre-Columbian buildings, and which are considered to have special meaning for the contemporary communities. In some cases the term refers to a building or a "tomb" itself. According to Nan Lo'xh:

Kamawiil's, these are the works of our Ancestors, even from thousands of years ago! This is what kamawiil means. They made things, these were their works. So this is why sometimes they excavate pots or stones from below the ground. They made their saints, their holes. (...) Some of them lived and some of them died, but below their pots, so under the ground, so that's why kamawiil is what they call them, because they don't know their name. They are handworks, our Ancestor's things that were left in the hole. So because of this, sometimes when they say that there are kamawiil's, sometimes it makes a sound when someone

\footnotetext{
${ }^{24}$ B. N. Colby and L. M. Colby, El Contador de Los Dias. Vida y Discurso de un Adivino Ixil, p. $41-42,181-183$.
} 
passes over them. It's because there are the important things or the materials of our Ancestors. This is why they are called kamawiil's. (Nan Lo'xh, Ilom, Chajul)

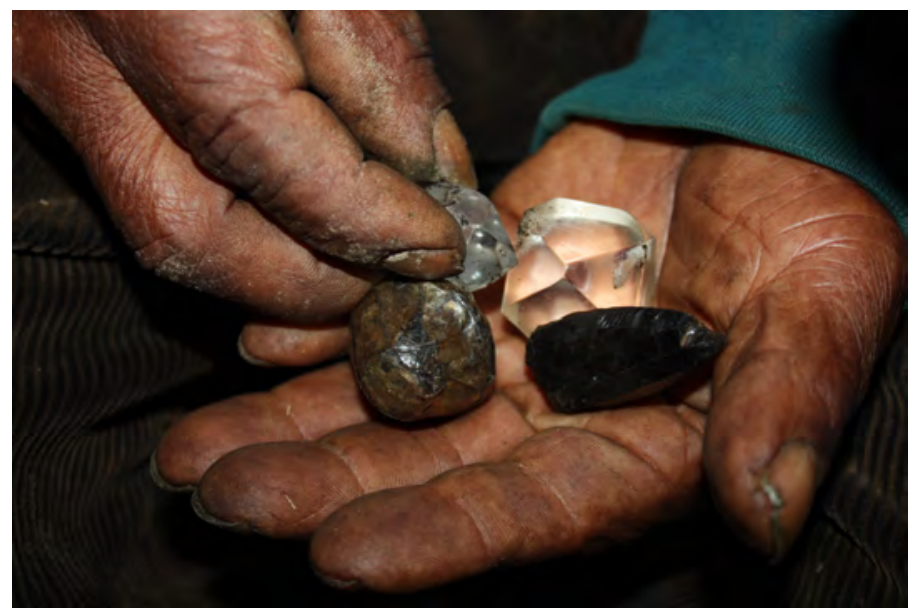

Kamawil's are considered to keep the power of the sacred places so it is not recommended to remove them. They are also used to perform divination, being part of what is called vara - a sacred bundle that serves to compose a divination table (may also contain red grains of Erythrina berteroana, called in Ixil mitx, maize grains, and other kind of objects, like pieces of plastic crystals or marbles). Don Bartolome describes kamawiil as elements that are made of such good materials that they are not even subject to destruction or decomposition:

These are the same people that made the pots in the past; it's a bone but now it looks like a stone, but it belongs to the Ancestors. And their tools [are made of] some good material that they used. Who knows how many years [had passed] but those materials and these bones of the Ancestors - they never rot, because they used such good material. What happened to them is the greatest judgment...! (Don Bartolome, Ilom, Chajul)

He also mentions that his grandfather used to tell him that in the past, crossing the Ancestor's places at the "wrong hour" could make the objects laying down there cause some bad luck. Today it is believed that in general visiting any of the sacred places should be followed by making at least a small 
offering or greeting to the Ancestors (especially if other places are being attended, as the balance between honouring each of them is very important), but there are no major apprehensions about any possible unfortunate accidents or diseases that might be associated with the very fact of trespassing through the places of the Ancestors. One exception would be in the case of damage caused to the sites or parts of the sacred landscape. In this way, any unusual activities like excavations (even archaeological), construction or mining that are effectuated without the permission of the Grandfathers may end up with punishment or even death.

Pap Maxh, one of the elders of Ilom makes a meaningful point that illustrates the importance of the site of B'ayal I' and the identification of the people with their ancestral lands:

Yes, our K'uykumam [Grandfathers] where there, at the Kuxhab' [Achiote]. This is where the Ancestors were, but maybe "the company" got rid of them... There came a judgment, these were the people that lived there, they talked between each other about how to get to the sky and listen to the god. This is why the judgment came. There were people there. Maybe there is some kamawiil, who knows if they are [still] there. It's where the priests go to make their ceremonies, at Xe' Kuxhab', where "the company" [is]. If you go there they are going to shoot you... In the past they [the priests] went to burn the candle there too, now, there are police and soldiers there, at La Panchita, there are soldiers. All of La Panchita is ours, it belongs to Tx'ol, there was his costumbre back then. Who knows what was the face of Tx'ol, he was from Chajul, he was a Nam [Butterfly]. ${ }^{25}$ He was a very brave man, the Tx'ol. The soldiers from the capital have their guns and the land is their property, but it is all the land of the Tx'ol. But he doesn't come back... There is his house there; there is his pot there, but he is not coming. El patron [the owner] has finished his land. (Pap Maxh, Ilom, Chajul)

What has the greatest impact in Pap Maxh's words is the visible struggle between two realities. First of all, the certainty of belonging to the ancestral lands and the legitimacy of the Grandfather's existence at Xe' Kuxhab'

${ }^{25}$ In some of the variants of the Tx'ol Winaq narrative, he possess the ability to transform into a butterfly or become invisible in order to avoid bullets. 
is unquestionable. On the other hand, the historical forced land expropriation by the coffee plantations (sometimes called directly "the Spaniards") that was never brought to justice, the memory of the war, the presence of the military forces and the massacre of 1982, when all of the inhabitants of Ilom were accused of participating in the guerilla. As if this was not enough, there is also the ambivalent activity of the hydroelectric company in this sacred place; they bought it from the plantation and started developing the area (according to many - without conducting with anticipation a proper public consultation with the communities). This promised progress, however, is not really perceptible for the people of Ilom, given that after almost 10 years of the company's operations, their living standards seem to be worsening instead of improving. Furthermore, there is this powerful message that Don Francisco shares: "Our name was the Lacandon, that was our name because the Tx'ol was here and the Spaniards said that the Chajul [Ixil] were the Lacandon, as I heard when I was little. Later they no longer called us Lacandon but 'guerillas', this is how they called us." (Don Francisco, Ilom, Chajul). This demonstrates how the kinship with the Grandfathers, the sense of belonging to the ancestral lands, and the use of the Indigenous language that the oppressors did not make an effort to understand, had all became a form of racism, a trope of savageness, which contributed to the justification of the genocide committed against the Ixil people. Yet, Tx'ol Winaq remains a symbol of the fact that the Indigenous people could not be completely defeated - he survived, just like the Ixil people survived the Spaniards, the finqueros (plantation owners, ranchers) and survived the war:

Who knows what power he possess, who knows what power of the Vinq'elil Naj [Twenty Gods] he possess, this is why they could not kill him. If you have power they will not be able to kill you because you are invisible. We are indigenous people and Tx'ol is also indigenous, we are Chajul, that's why the Spaniards envy us... and all that happened during the war... but the god has let us, the indigenous people, revive a little bit. (Pap Maxh, Ilom, Chajul) 


\section{Conclusions}

What brings attention in different variants of the Ixil narratives is the direct association of the concept of ancestral beings to the particular locations within the sacred landscape of Ilom, including the remains of their former pre-Columbian settlements. Moreover, it shows the continuity of these concepts throughout the centuries and emphasizes the powerful bonds between the land and people that lie in the worldview of the Ixil. This bond is especially visible in the case of the sacred place of B'ayal I', from which the people of Ilom had been expropriated on multiple levels of understanding, many times throughout history. Its name was changed. It suffered mechanical destruction. It has been transformed by archaeological excavation; the remains of the Ancestors and their kamawiil's never came back to rest at the site. Yet, even challenged by different historical and modern dynamics, this sacred place retains a special meaning and supports the bond between the people and their ancestral lands.

The example of Ilom and B'ayal I' shows how - through oral tradition and rituals - people maintain their relationships with the entities that inhabit the pre-Columbian remains and that are part of the cosmovision associated with the surrounding landscape. On the one hand, they may be identified as sinful, "savage" and lacking in certain characteristics that would demonstrate their belonging to the "world of culture", but on the other hand, the narratives show that the binarisms rooted in the Western theory (as well as separation between nature and culture) may not apply here at all, or that they were imposed later - if only because the Ancestors are in many ways more advanced than the people of the following generation, and are recognized for their extraordinary skills.

The glory of the ancestral beings has been disrupted by the sin they were said to be guilty of - the arrogance of getting closer to the god, a category of sin that on deeper reflection may not actually overlap with the gods desire to communicate with the humanity they created, as the historical sources show. The divine anger and punishment that follows, pushes them into the underground, to their tombs, caves, and water pits where they dwell until today. Over the time, the defeated generation becomes a symbol of sinfulness and savageness that has been transferred on the people and their communities generation after generation, transformed into racism and repression. In the past it played a significant role in different historical processes and now it continues to influence the notions of development and the processes of modernization. 


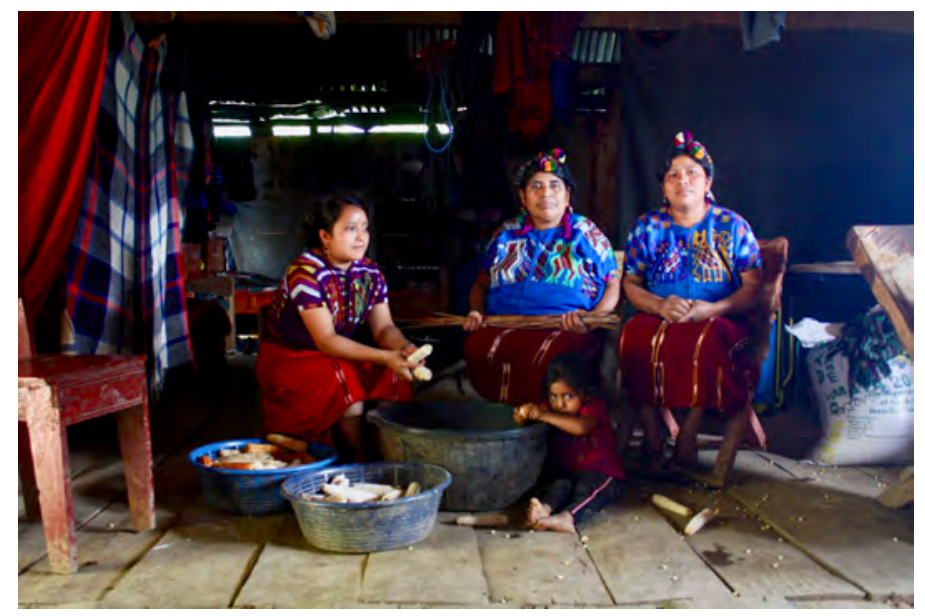

Despite the ambivalence that the narratives reveal, the people from the Ixil Maya communities such as Ilom consider those beings as their Ancestors and identify the existing genealogical relationship. Moreover, they manifest a strong affinity with their material and spiritual heritage recognizing in it the legacy of their Grandfathers. The relationships between the people and the K'uykumam, Tx'ol Winaq, the Lacandons, the Ancestors, the Ancients or the Grandfathers is strong enough to continue to recognize them as a part of their local identity and consider the places where they dwell as sacred, effectuating religious ceremonies and leaving offerings to give them respect.

\section{Bibliography}

1. Batz G., The Fourth Invasion: Development, Ixil-Maya Resistance, and the Struggle against Megaprojects in Guatemala, Ph.D. Dissertation, University of Texas at Austin, 2017.

2. Becquelin P., Breton A., and Gervais, V. Arqueología de la Regíon de Nebaj, Guatemala. Cuadernos de Estudios Guatemaltecos, Centro Francès de Estudios Mexicanos y Centroamericanos, Escuela de Historia USAC, Ministerio de Asuntos Exteriores de Francia (CCCAC), Mexico and Guatemala 2001, Vol. 5 .

3. Carmack R. M., The Quiché Mayas of Utatlán, The Evolution of a Highland Guatemala Kingdom. University of Oklahoma Press, Norman 1981.

4. Christenson A. J., Popol Vuh. Sacred Book of the Quiché Maya People, Mesoweb Publications, 2007, [www 01] (access: 15.07.2017). 
5. Colby B. N., and L. M. Colby. El Contador de Los Dias. Vida Y Discurso de un Adivino Ixil, Fondo de Cultura Económica, Mexico1981.

6. de Vos J., La Paz de Dios y Del Rey. La Conquista de La Selva Lacandona (1525-1821), Fondo de Cultura Económica, Mexico 1988.

7. Elliott E. D., Gaspar Ilom: Maya Resistance to the Western Ideology of Nature, MA Dissertation, University of San Diego, 1998.

8. Gossen G. H., Chamulas in the World of the Sun, Harvard University Press, Cambridge 1974.

9. Hermes B., and J. L. Velásquez, Analisis de La Cerámica Arqueológica de Xacbal, Chajul, Quiché: Períodos Preclásico Y Clásico Temprano, "Contributions in New World Archaeology" 6 (2014), pp. 111-34.

10. Knowlton, T., Maya Creation Myths, University Press of Colorado, Colorado 2017.

11. La Farge, O. and Douglas B., El Pueblo del Cargador del Año. Yax Te' Foundation, South Woodstock, VT: Plumsock Mesoamerican Studies, Rancho Palos Verdes, CA 1997.

12. Lévi-Strauss C., The Culinary Triangle, [in:] Counihan, C. and Van Esterik P. Food and Culture: a Reader, Routledge, London 2008, p. 36-43.

13. Lincoln J. S., Ethnological Study on the Ixil Indians, microfilm (positive) copy of typescript, University of Chicago Library, Chicago 1945.

14. Tedlock D., Creation in the Popol Vuh: A Hermeneutical Approach, [in:] Gossen G., Symbol and Meaning Beyond the Closed Community-Essays Un Mesoamerican Ideas, Institute of Mesoamerican Studies, New York 1986, p. 77-82.

15. Thompson J. E. S., Maya History and Religion, University of Oklahoma Press, Norman 1976.

16. Thompson J. E. S., Sixteenth and Seventeenth Century Reports on the Chol Mayas, "American Anthropologist" 40, 4 (1938), pp. 584-604.

\section{Internet sources utilised:}

[www 01] https://mesoweb.com/publications/Christenson/PopolVuh.pdf 